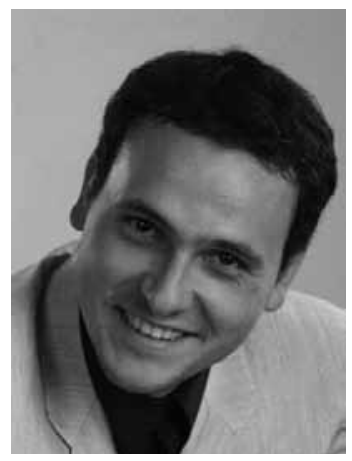

\title{
А.А. Кудрявцев
}

Харківська медична академія післядипломної освіти

Кафедра терапії, ревматології та клінічної фармакології

\section{Роль та місце греліну у патологіi захворювань органів шиунково- кишкового тракту}

$\mathrm{C}$ ьогодні деякі науковці виокремлюють негативні тенденції в тріаді статистичних показників стану здоров'я населення України, а саме: відтворення населення (медико-демографічні дані); розвиток дітей, запас фізичних сил у дорослого населення (фізичний розвиток); адаптація населення до умов навколишнього середовища (захворюваність, інвалідність). Експерти ВОО3 і вітчизняні науковці називають чинники розвитку цих негативних тенденцій та вказують на такі детермінанти здоров'я: соціально-економічний стан і стан довкілля, якість харчування та питної води, зростаюче розшарування населення за рівнем доходів, організація надання медичної допомоги тощо [40, 47].

На тлі таких висновків, актуальною проблемою сучасної медицини є захворювання органів травлення. Ïх медико-соціальна значимість обумовлена тим, що на цю патологію страждають всі вікові групи населення. [94].

Спектр цих захворювань досить широкий і різноманітний; оскільки вони є багатофакторними. Виділяють такі основні фактори, що сприяють розвитку хвороб органів травлення: стрес, робота, пов'язана 3 нахилом тулуба, ожиріння, паління, хіатальна кила, вживання деяких лікарських засобів (антагоністів кальцію, антихолінергічних препаратів, бета-адреноблокаторів та ін.), нераціональне харчування, вагітність [64].

Групою вчених [63] визначено групи ризику щодо розвитку патологічного рефлюксу: особи з обтяженою спадковістю щодо захворювань органів шлунково-кишкового тракту, переважно чоловічої статі, 3 органічною патологією гастродуоденальної зони, вегетативною дисфункцією, вогнищами хронічної інфекції, в т.ч., глисно-паразитарною інвазією, ожирінням, мезенхимальною недостатністю та ін.

I в усьому світі, і в Україні, показники захворюваності на ХOT прогресивно зростають і подвоюються щодесятиліття [31].

За результатами епідеміологічних досліджень, до $50-60 \%$ дорослих і до 30-40\% дітей, що звертаються до лікарів-гастроентерологів, страждають різними функціональними розладами системи органів травлення. ВООЗ констатує: за останні 60 років захворюваність на вказані розлади зросла у 24 рази.

За даними світової статистики, функціональна диспепсія (ФД) є четвертим за частотою діагнозом, який установлюють сімейні лікарі та терапевти за результатами первинних оглядів пацієнтів.

У країнах Західної Європи (Данія, Швеція, Норвегія, Велика Британія), частота синдрому диспепсії серед дорослого населення коливається від 25-28\% до $43-52 \%$.

Результати популяційних досліджень свідчать, що симптоми диспепсії частіше визначаються у жінок (55-60\%), ніж у чоловіків (40-45\%). При цьому тільки в 33-40\% випадків диспепсичні прояви пов'язані 3 хронічними захворюваннями шлунково-кишкового тракту, а в 60-67\% виставляється діагноз функціональна диспепсія. Незважаючи на таку поширеність у популяції, на сучасному етапі не повністю розкриті етіопатогенетичні механізми функціональної диспепсії, існують певні труднощі у верифікації діагнозу, що лежить в основі недостатньої ефективності проведеної терапії [21].

Інші результати епідеміологічних досліджень доводять, що поширеність гастроезофагеальної рефлюксної хвороби (ГЕРХ) у країнах Західної Європи 
та Північної Америки становить 30-40\% дорослого населення, 3 них 10\% відчувають печію щоденно, проте тільки 2\% пацієнтів отримують лікування 3 приводу цієї патології. У Японії, де ендоскопічне обстеження верхніх відділів шлункового каналу є скринінговим, частота виявлення езофагітів становить 16,5\% від всіх обстежених осіб [38].

Оскільки в Україні статистична реєстрація ГЕРХ почалася з 2009 року, то дані ще не є повними, але захворюваність складає 10 випадків на 1000 населення [7], що складає від 11,1\% до 30\% [32]. Але, науковці стверджують, що реальна поширеність ГЕРХ може бути значно більшою, оскільки близько 25\% хворих на ГЕРХ не звертаються до лікарів, займаються самолікуванням, а у частини пацієнтів ГЕРХ має безсимптомний перебіг [36]. Відповідно, результати цих досліджень доводять факт зростання частоти виявлення ерозивної форми ГЕРХ із 3,1 до $16,0 \%$, зростання з віком захворюваності на рефлюкс-езофагіт $(\mathrm{PE})$, та виявлення його ускладнень у хворих старше 50 років $[8,34]$.

Офіційна статистика констатує, що в Україні з 2013 р. в групі хвороб органів травлення окремо реєструються нозологічні форми: неспецифічний виразковий коліт, хвороба Крона, синдром подразненого кишечнику [31].

Актуальність зазначеної проблеми посилюється тим, що захворювання органів травлення впливають на зниження якості життя людини $[90,95]$.

Так, висока поширеність синдрому диспепсії серед населення визначає великі витрати, яких зазнає охорона здоров'я на обстеження та лікування таких пацієнтів [57].

Відомо, що майже 25\% хворих на функціональну диспепсію звертаються до лікаря більше 4 разів на рік, а пацієнти з хворобами органів травлення в 2,6 рази частіше, ніж інші, перебувають на лікарняному протягом року, при чому термін непрацездатності на 3-4 тижні довше в порівнянні з середніми показниками, розрахованими для всього населення [85].

Слід визнати, що сьогодення характеризується зростанням гастроентерологічної патології серед дітей. За даними ДУ «Український інститут стратегічних досліджень МО3 України» у 2015 році цей показник становив 117,07 на 1000 населення віком 0-17 років [24]. При чому, в структурі гастроентерологічних захворювань у дітей одне з провідних місць посідає гастроезофагеальна рефлюксна хвороба (ГЕРХ), частка якої, за даними різних авторів, становить від 8 до $25 \%[28,38]$.

У дітей на підставі езофагогастродуоденоскопії, рефлюксезофагіт виявляється у 23\% випадків, а у старшої вікової групи (12-15 років) ГЕРХ діагностується у кожної другої дитини.

Відомий факт, що в Україні щороку вперше реєструють майже 1000 дітей із виразковою хворобою [43], відзначається чітка тенденція до зростання частоти таких серйозних ускладнень ГЕРХ, як стравохід Барретта і аденокарцинома стравоходу.

Педіатри стверджують, що саме ГЕРХ є одним із найбільш вивчених захворювань органів травлення у дітей, при цьому постійно оновлюються рекомендації з критеріїв діагностики та $[55,56,87]$.

Але, незважаючи на досягнення значних успіхів у вивченні різних аспектів етіології, патогенезу та лікування цих захворювань, зокрема, виразкової хвороби ДПК, це питання є актуальним і привертає увагу провідних гастроентерологів та педіатрів [36].

Також, слід звернути увагу на результати дослідження функціональних розладів шлунково-кишкового тракту в дітей та підлітків, отримані [19]. Функціональні розлади частіше реєструються у віці 14-17 років та 3 більшою частотою $(\mathrm{p}<0,05)$ у дітей, які зазнали впливу психотравмуючих чинників зовнішнього середовища. Виявлено, що в дітей та підлітків дослідної групи частіше визначалися два або більше розладів з боку шлунково-кишкового тракту: найчастіше одночасно проявлялися функціональна диспепсія, синдром подразненої кишки та аерофагія $(\mathrm{p}<0,05)$.

Саме це викликає занепокоєння станом здоров'я молоді, особливо студентської й учнівської, як найбільш вразливих і незахищених груп населення. Високий рівень розвитку патології шлунково-кишкового тракту у цієї групи, її зростання залежно від курсу, обумовлений специфікою умов їхнього життя. [1].

Зауважимо, що функціональні розлади шлунковокишкового тракту не несуть загрози для життя паці-

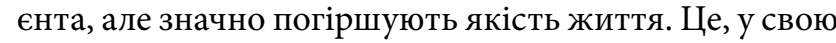
чергу, спричиняє великі економічні збитки для суспільства, оскільки поширеність диспепсичних скарг серед дорослого населення досягає $45 \%$, а по медичну допомогу звертаються лише до 25\% пацієнтів [53,78].

Ще одним питанням визначеної проблеми $є$ захворювання органів травлення серед військовослужбовців в Україні [65].

В доступних наукових дослідженнях підкреслено, що серед хвороб органів травлення в учасників АТО переважають кислотозалежні захворювання (78\%), з них ерозивно-виразкові ушкодження езофагогастродуоденальної зони виявляються у 92,4\%, ГЕРХ - 32,9\%, що мають торпідний та ускладнений перебіг, часта асоціація з психоформними розладами та порушення трофологічного статусу. Хронічні захворювання органів травлення, що виявляються у військовослужбовців під час поглибленого медичного обстеження, посідають перше рангове місце серед хронічної патології [25].

Науковці зазначають, що хвороби органів травлення суттєво впливають на професійну дискваліфікацію військовослужбовців 3С України, що окрім соціальних наслідків наносить значні економічні збитки нашій державі. У структурі хвороб органів травлення, які стали причиною зміни категорії придатності військовослужбовців переважають хвороби стравоходу, шлунка та дванадцятипалої кишки.

Аналіз особливостей та структури захворюваності органів травлення у військовослужбовців 3СУ дає змогу припустити, що існує зв'язок 3 характером сучасних бойових дій та особливостями перебігу захворювань ШКТ, які включають в себе: коморбідність, переважання кислотозалежних захворювань 
3 ерозивно-виразковими ушкодженнями, частий ускладнений перебіг, асимптомність, множинність супутніх захворювань, поєднання 3 психоформними розладами. Визначено, що частка захворюваності органів травлення у військовослужбовців ЗСУ після початку бойових дій збільшилася та становить 45,8\%, посідаючи 1-ше місце в загальній структурі терапевтичної патології [42].

Вищезазначене дає підстави стверджувати, що сьогодні захворювання набувають статусу коморбідності. Так, з'являються комбінації захворювань, які раніше зустрічалися рідко, наприклад, виразкова хвороба й ішемічна хвороба серця; хронічний гастродуоденіт і дисліпідемія; цукровий діабет і виразкова хвороба, виразкова хвороба та бронхіальна астма $[18,35]$, і кислотозалежні захворювання [10, 30].

Науковцями описано та вивчено такі поєднання захворювань як ішемічна хвороба серця та цукровий діабет $[4,15]$; артеріальна гіпертонія й ішемічна хвороба серця $[17,27]$, артеріальна гіпертонія й ожиріння [2]; жовчокам'яна хвороба та діафрагмальна нориця $[3,5,10]$; ерозивне ушкодження гастро-дуоденальної зони та хронічні бронхолегеневі захворювання [23].

Отже, значення проблеми коморбідності для практичної діяльності обумовлене наявністю низки захворювань із хронічним перебігом, та призводить до погіршення якості життя.

Останніми роками дедалі більшої уваги приділяють вивченню проблеми поєднання патології органів травлення з іншими патологічними станами, зокрема 3 ожирінням, цукровим діабетом 2 типу, артеріальною гіпертензією $[12,20,34]$.

Таким чином, слід констатувати, що упродовж останнього десятиріччя в загальній структурі захворювань, саме гастроентерологічні захворювання посідають третє місце, зокрема в економічно розвинутих країнах, а їхні медичні аспекти мають велику соціально-економічну значущість, оскільки пов'язані з передчасною інвалідизацією й смертністю хворих, зокрема працездатного віку. Отже, поширеність хвороб органів травлення (XОT) на сучасному етапі надзвичайна та оцінюється як епідемія. Найчастіше функціональні захворювання діагностують в осіб молодого працездатного віку (20-45 років), як серед представників інтелектуальних професій, так і серед тих професій, що мають підвищену стресогенність, вимагають значних психофізіологічних витрат, пов’язаних з ризиком для здоров'я та життя.

Відповідно до вищезазначеного, існує нагальна потреба вивчення центральних механізмів формування захворювань шлунково-кишкового тракту, а саме ролі центральної нервової й ендокринної систем.

\section{Загальні відомості про грелін}

Сьогодні науковці значну увагу приділяють біохімічним і молекулярним механізмам, що лежать в основі розвитку цих патологій. Зусилля лікарів-дослідників спрямовані на якомога раннє виявлення захворювань та призначення адекватної комплексної терапії. За останні роки відкриті нові гормони та нейромедіатори, які регулюють енергетичний обмін і харчову поведінку, у тому числі грелін (ghrelin) - гастроінтестинальний гормон, що виявляє різні біологічні властивості та ефекти: стимулює вивільнення гормона росту, стимулює апетит, спричиняє анаболічну дію, впливає на вуглеводний обмін [67].

Саме тому цьому питанню ми приділяємо увагу. Отже, клітини шлунка виконують екскреторну й інкреторну функцію, виробляють грелін - орексигенний гормон, що складається з 28 амінокислот, має молекулярну масу 3,3 кДа [70].

Основний сайт синтезу греліну - шлунок, на 2 місці - дванадцятипала кишка, менш виражені концентрації наявні в усьому шлунково-кишковому тракті, але зменшуються у дистальному напрямку. У межах шлунка синтез греліну здійснюється ентероендокринними клітинами в кислотопродукуючій слизовій оболонці, які раніше мали назву «X/А-подібні клітини» 3 неуточненою функцією. Кількість цих клітин складає приблизно $20 \%$ від загальної кількості ендокринних клітин слизової оболонки шлунку. Ряд науковців виділяє їх в окрему групу грелін-продукуючих клітин ghrelin-producing cells (Gr cells) [50]. Більшість цих клітин прилягає до базальної мембрани, не контактує безпосередньо з просвітом шлунку, виділяє грелін безпосередньо в кров [65]. Це свідчить про те, що функціонально ці клітини не залежать від впливу фізико-хімічних стимулів вмісту шлунку.

У невеликих кількостях грелін також продукують легені, острівці підшлункової залози, гонади, кора наднирників, плацента, гіпоталамус.

Гормон також визначений у нейронах, суміжних регулюючим енергетичний баланс, та утворюючих синапси з нейронами, що синтезують нейропептид $\mathrm{Y}$, що збуджує апетит і білок Agrp (агуті), а також з іншими нейронами, що беруть участь в енергетичному гомеостазі. Питання центральної продукції греліну $€$ дискусійним, оскільки обговорюється можливість його проходження в гіпоталамус через гемато-енцефалічний бар'єр [76].

Грелін утворюється з більш крупного попередника - препрогреліну, що складається зі 117 амінокислот [65]. Пептид підлягає післятрансляційній модификації, при цьому радикал серін-3 ковалентно зв'язується зі середньоланцюговими жирними кислотами через складний етерний зв'язок. Цей тип ацилірування унікальний для греліну та необхідний для того, щоб пептид зв'язався з його рецептором GHS-R1a. Активація греліну відбувається за рахунок дії ферменту грелін-О-ацилтрансферази [83]. Отже, для реалізації біологічних ефектів греліну необхідно його ацилірування [65].

Співвідношення ацилованого греліну до дезацильних форм приблизно однакове в тканинах, що його синтезують (шлунок), а також в крові. Відповідно, ацилірування відбувається в клітинах джерела. Деякі наукові дослідження дозволяють зробити висновок, що високий рівень дезацильного греліну може інгібувати деякі впливи ациліруваного греліну [76].

Науковцями доведено, що грелін впливає на апетит не тільки прямою передачею сигналів до ромбо- 
подібного мозку, але й через блукаючий нерв, оскільки його еферентні шляхи стимулюють вивільнення греліну [80]. Грелін експресується багатьма іншими периферійними тканинами та центральною нервовою системою [68]. Недавніми дослідженнями було встановлено, що він тісно пов'язаний з мозковими функціями (навчання, пам'ять, збудження, стрес).

Основні ефекти греліну

На сучасному етапі відомі біологічні ефекти греліну, а саме:

1. Регуляція апетиту - одна з важливіших функцій греліну [67]. Грелін сприяє передобідньому голодуванню, ініціює приймання їжі. Збуджуюча апетит дія греліну средньошвидка та короткодіюча. Рівень греліну плазми у людини швидко знижується після прийому їжі, у добовому профілі греліну плазми наявне значне препрандіальне збільшення до величин, стимулюючих прийом їжі й апетит, постпрандіальне зниження греліну. За рахунок підвищення апетиту відмічається збільшення вживаної їжі, що призводить до підвищення секреції шлункового соку, а також розтягування шлунку. Ці процеси провокують розвиток ГЕРХ, кили стравохідного отвору діафрагми, гастритів з підвищеною кислотністю та інших захворювань органів ШКТ.

2. Анаболічні ефекти: підвищує апетит, сприяє ожирінню, збільшенню м'язової маси, підвищує рівень глюкози в крові. Грелін блокує інгібуючий ефект інсуліну на глюконеогенез, можливо, спроможний прямо стимулювати глюконеогенез [47]. Грелін називають гормоном голоду, оскільки підвищення його рівня у плазмі крові асоціюється з виникненням відчуття голоду. Грелін стимулює споживання їжі, бере участь в регуляції енергетичного гомеостазу [21]. Підвищення апетиту провокує збільшення кількості вживаної їжі, що призводить до підвищення секреції органів травлення. Зростає навантаження на підшлункову залозу, печінку, жовчний міхур, оскільки їм треба виділяти все більше ферментів та свого секрету для перетравлення збільшеного об’єму їжі. Це призводить до їх швидкого виснаження, що проявляється розвиненням таких захворювань, як панкреатит, холецистит, жовчо-ка'мяна хвороба.

3. Вплив на секрецію гормонів: підвищує вивільнення гормону росту. Стимулювання його вивільнення відбувається різними шляхами: через прямий вплив циркулюючого греліну на гіпофиз; через блукаючий нерв; через прямий ефект греліну, що знаходиться в гіпоталамусі. Рецептором греліну, що зумовлює його сильний ендогенний стимулюючий ефект $\epsilon$ GHS-R1a. 3 урахуванням участі блукаючого нерву у регуляції концентрації греліну у плазмі крові, можливе порушення секреції клітинами шлунку, підшлункової залози, печінки при порушенні регуляції греліну. Це призводить до розвитку гастритів із зміненням кислотності шлункового соку, панкреатиту, холециститу, жовчо-кам'яної хвороби, ГЕРХ. $[91,97]$. Грелін незначно підвищує вивільнення гормонів: аденокортикотропного, кортизолу, пролактину, неоднозначно впливає на вивільнення інсуліну, що також відображається на посиленні апетиту та розвитку захворювань ШКТ - панкреатит, холецистит [65]; регулює рівень адреналіну у крові [66], впливає на синтез різних ферментів, процеси травлення, кров'яний тиск, рівень цукру в крові, інсуліну, ефективність роботи серця та інші фізіологічні показники [52].

4. Вплив на серцево-судинну систему: має кардіопротекторний ефект при ішемії, посилює вазодилатацію та регулює артеріальний тиск [16,59]. Зниження артеріального тиску обумовлено прямою дією греліна на ендотелій або гладком'язові елементи судинної стінки [92]. Поліпшує функцію лівого шлуночка при хронічній серцевій недостатності [94], Знижує системний судинний опір та збільшує серцевий викид та серцевий індекс у пацієнтів 3 хронічною серцевою недостатністю [73].

Наукові дані $[40,41,86]$ свідчать, що грелін має також захисний ефект проти киснево-глюкозного обмеження, ішемії та реперфузії. В експерименті було встановлено, що ін'єкції греліну покращують скоротливість міокарда, знижують середній артеріальний тиск без змін серцевого ритму у здорових людей, а також зменшують ремоделювання лівого шлуночка [81]. 3 урахуванням захисного ефекту проти киснево-глюкозного обмеження, ішемії і реперфузії, при зниженні концентрації греліну у плазмі крові можливе розвинення ішемічних уражень органів ШКТ, а саме мезентеріальних тромбозів, тощо.

5. Вплив на шлунково-кишковий тракт: підвищує продукцію соляної кислоти у шлунку, підвищує рухову активність шлунку, підвищує відновлення слизової оболонки шлунку та кішківника $[29,66]$. Відіграє важливу роль у регуляції біохімічних процесів, пов'язаних із травленням, в основному через вплив на синтез різних ферментів [79].

6. Вплив на кісткову тканину: впливає на проліферацію та диференціювання остеобластів, підвищує IMT [65]. Посилює літогенез в кістковому мозку [84]. 3 урахуванням підвищення маси тіла, можливий розвиток цукрового діабету II типу на тлі хронічного панкреатиту.

7. Можливо, здатний до інгібування імуноглобуліну Е прямим або непрямим способом, має захисний вплив на клітини, модулюючий ефект клітинної проліферації, імунологічну регуляцію і протизапальний ефект [69]. Порушення у цій системі призводить до розвитку автоімунних процесів у органах ШКТ хвороби Крона, неспецифічного виразкового коліту.

У наукових джерелах наявні дані, що низькі рівні греліну в плазмі асоціюються з інсулінорезистетністю та гіпертензією та можуть впливати на показники артеріального тиску [13].

Визначена обернена залежність грелінемії та інсулінорезистентності: чим нижчий його рівень, тим більш виражена інсулінорезистентность [45,77]. Низький рівень греліну може бути показником ризику діабету II типу та гіпертензії.

[32] вважає, що жирова тканина, як ендокринний орган, синтезує адипоцитокіни (лептин, адипонектин, резистин, грелін тощо), які не тільки контролюють метаболізм, але й беруть участь в гормональній 
регуляції репродуктивних функцій. Ожиріння у вагітних жінок асоціюється з інсулінорезистентністю та гіперінсулінемією, які $є$ патогенетичною основою складних метаболічних порушень.

[49] доведено, що грелін стимулює диференціацію преадипоцитів та пригнічує ліполіз in vitro.

У публікаціях [34] розглянуто вплив греліну на скорочувальну активність травної системи, що обумовлений його структурними особливостями, оскільки за своєю будовою він подібний гастроінтестинальному гормону мотиліну (гомологічність становить $36 \%$, а спорідненість між рецепторами цих речовин близько 50\%). Вивчення особливостей впливу греліну на гастроінтестинальну моторику при парентеральному введенні пацюкам, дало підстави стверджувати, що він індукує підвищення частоти міграції рухового комплексу, що супроводжується збільшенням моторної активності гастроінтестинального тракту натщесерце, прискоренням спорожнювання шлунка і не впливає на показники базальної кислотності [71]. У 2005 році [72] отримали подібні результати при застосуванні греліну у людей, хворих на діабетичний гастропарез.

[66] стверджують, що підвищення вмісту греліну, стимулює синтез орексигенних факторів та збуджує апетит, обумовлює зміни харчової поведінки та розвиток гіперфагії.

[26] зазначає, що у пацієнтів із функціональною диспепсією виявляються зміни рівня загального греліну та греліну натще, також рівень греліну в крові достовірно корелює 3 випорожненням шлунка та клінічною симптоматикою.

[9] довели, що підвищення рівня ацил-греліну $\epsilon$ маркером неалкогольної жирової хвороби печінки у хворих на цукровий діабет 2 типу.

$€$ дані, що при ожирінні та метаболічному синдромі концентрація циркулюючого греліну знижується, а на продукцію його може впливати рівень ліпідів [11]

[58] вивчали базальний та постпрандіальний рівень греліну в сироватці крові, його зв'язок з типами харчової поведінки (ХП) та появою закрепів у хворих із синдромом подразненої кишки (СПК) на тлі ожиріння та дійшли висновку, що відсутність зниження рівня греліну після прийому їжі у хворих із СПК на тлі ожиріння різного ступеня є мотиваційним чинником повторних епізодів їди, а через вплив на харчову поведінку та стреси спричиняє формування закрепів.

Нез'ясовані аспекти впливу греліну на виникнення захворювань шлунково-кишкового тракту

Насьогодні залишається невивченою роль греліну (Ghr) в патогенезі ожиріння, немає єдиної думки про взаємозв'язок його з гормональними та метаболічними чинниками, що сприяють формуванню ожиріння, у змінах ліпідного спектру крові.

Недостатньо вивчений механізм, завдяки якому поживні речовини інгібують синтез греліну. Але, відомо, що вуглеводи є більш ефективними, ніж білки, а білки більш ефективними, ніж ліпіди. Порівняно слабка супресія гормону жирами збуджує апетит та може пояснювати механізм збільшення ваги тіла, що індукований дієтою з високим вмістом жирів. Постпрандіальна супресія греліну не потребує впливу харчових речовин безпосередньо на порожнину шлунка та дванадцятипалої кишки - визначними $\epsilon$ процеси, що відбуваються після абсорбції в кишківнику [94].

Рівні греліну виявляють зворотню кореляцію між ожирінням, рівнями лептину й інсуліну. При голодуванні рівень греліну (Ghr) підвищується, і він, імовірніше, відіграє роль антидепресанту. Концентрація греліну у крові має зворотню кореляцію з IMT, жировою масою тіла, розміром адипоцитів, концентрацією лептину, обестатину, з позитивним енергетичним балансом [88].

Грелін підвищується у відповідь на втрату ваги (низькокалорійні дієти, модифікація способу життя (аеробіка), ракова кахексія, нервово-психічна анорексія, хронічні недостатності: серцева, ниркова, печінкова. При збільшенні ваги (лікування глюкокортикоїдами) грелін знижується. При тотальній гастроектомії, що проводиться для лікування раку або виразкової хвороби, відмічалася редукція концентрації греліну плазми, що вимірювалася через 30 хвилин після операції, на 30-50\%. У подальшому також спостерігалося зниження рівня греліну плазми [65].

У наукових дослідженнях хронічної хелікобактерної інфекції та спричиненого нею хронічного атрофічного гастриту, неодноразово відмічалася негативна кореляція між вираженостю атрофічного процесу в шлунку та рівнем циркулюючого греліну плазми [75]. Виявлено, що хронічна Н. pylori інфекція сприяє зменшенню шлункових грелінімунореактивних клітин [78]. Це підтверджено у дослідженнях [14], які констатують, що Н. pylori-статус впливає на регуляцію утворення греліну та лептину. Ерадикація Н. pylori значно підвищує індекс маси тіла внаслідок вираженого збільшення рівня греліну і зменшення вмісту лептину в плазмі крові [22].

Результати наукових досліджень педіатрів демонструють, що у дітей у препубертатному віці з недостатністю харчування, концентрація сироваткового ацилгреліну зворотно пропорційна вираженості Нр-асоційованого гастриту. У дітей ерадикація Нр пов'язана зі значним підвищенням IMT, худої та жирової маси [96].

Заслуговують на увагу дані про асоційоване зі зниженням ацил-греліну погіршення нутриційного статусу [48]. Науковці виявили порушення пропорції між ацил- и дезацилірованими формами греліну у дітей, що отримують терапію гемодіалізом. Аналогічні дані отримані [74].

Значущими є роботи [51], які демонструють факт, що при введенні греліну та агонистів його рецепторів відмічається підвищення споживання їжі, збільшення приросту худої маси тіла та зниження деградації м'язового білка у мишей після нефроектомії. Схожі результати отримані [44], які продемонстрували комбінований ефект греліну на апетит і мітохондрії м’язів, що виявлявся збільшенням худої маси й по- 
ліпшенням виживання пацієнтів 3 термінальною нирковою недостатністю.

При визначенні рівня загального греліну в плазмі у пацієнтів 3 зермінальною нирковою недостатністю в роботах [61] було продемонстровано підвищення концентрації греліну серед пацієнтів даної групи.

При оцінці отриманих результатів, що суперечать очікуваним, висувалися припущення про можливий розвиток резистентності гіпоталамічних центрів до греліну при наявності його у високих концентраціях. Однозначне тлумачення цього факту відсутнє.

\section{Результати власних досліджень}

Вивчення концентрації греліну у плазмі крові у пацієнтів із ГЕРХ та цукровим діабетом (ЦД) 2-го типу в осіб молодого віку стало частиною нашого дослідження.

Показано, що концентрація греліну знижується при різних метаболічних процесах, у тому числі при цукровому діабеті 2-го типу. Цей гормон відіграє важливу роль у регуляції функцій органів шлунково-кишкового тракту. На розвиток постпрандіальної гіперглікемії також впливає зниження концентрації греліну, що призводить до уповільнення спорожнення шлунку, що є однією з патогенетичних ланок розвитку ГЕРХ і ЦД 2-го типа. Грелін також впливає на метаболізм глюкози й інсуліну, тому зміна його рівня в крові негативно впливає на глікемічний профиль пацієнтів, клінічний перебіг і тяжкість симптоматики ЦД 2-го типу. Для отримання результатів ми дослідили чотири групи пацієнтів, хворих на ГЕРХ із супутнім цукровим діабетом 2-го типу легкої та середньої тяжкості й ізольованої ГЕРХ.

Нами встановлено, що на тлі проведення 4-х-тижневого курсу лікування у пацієнтів усіх чотирьох груп збільшився рівень греліну та знизилися показники окислювального стресу. Так, у групі пацієнтів 3 ізольованою ГЕРХ, що отримували додатково актовегін, показники греліну збільшилися у середньому з 3,5 нг/мл до 4,7 нг/мл і практично наблизилися до показників контрольної групи (5,0 нг/ мл) $(\mathrm{p}<0,05)$. У пацієнтів із ГЕРХ, що не отримували актовегін, динаміка росту греліну була нижчою: 3,6 нг/мл до лікування та 4,1 нг/мл після.

У пацієнтів із ГЕРХ із супутнім цукровим діабетом 2-го типу, що отримували актовегін, також відмі- чалася тенденція до зростання греліну: 1,2 нг/мл до лікування та 4,5 нг/мл після лікування. При цьому ця динаміка була значно краще, ніж у пацієнтів 3 ГЕРХ із супутнім цукровим діабетом 2-го типу, що не отримували додатково актовегін - 1,1 нг/мл до лікування та 3,4 нг/мл після.

Отримані дані дозволили уточнити взаємозв'язок греліну з оксидативним стресом при наявності коморбідного перебігу ГЕРХ із ЦД 2-го типу в осіб молодого віку, що висвітлюється у попередній нашій публікації (Роль грелина в формировании коморбидного течения гастроэзофагеальной рефлюксной болезни с сахарным диабетом 2-го типа у лиц молодого возраста, Опарін О.А., Опарін А.Г., Кудрявцев А.А., Східноєвропейський журнал внутрішньої та сімейної медицини).

Отже, результати, отримані нами у ході дослідження, свідчать, що грелін відіграє важливу роль у формуванні коморбідного перебігу ГЕРХ із ЦД 2-го типу в осіб молодого віку та констатують, що зміни рівня греліну є одним із чинників, що значно обтяжує клінічний перебіг ГЕРХ із ЦД 2-го типу.

Також слід зазначити, що одночасно з нормалізацією рівня греліну у групах пацієнтів, що хворіють на ЦД 2-го типу, відмічалася чітка тенденція до стабілізації глікемічного профілю, що свідчить про тісний зв'язок між цим гормоном і клінічним перебігом цукрового діабету 2-го типу.

Отримані дані дозволяють стверджувати, що поперше, грелін відіграє важливу роль у патогенезі та клінічному перебігу цієї коморбідної патології; подруге, зміни рівня греліну й оксидативний стрес $€$ одним із пускових механізмів формування ГЕРХ у поєднанні 3 цукровим діабетом 2-го типу в осіб молодого віку, по-трете, грелін сприяє обтяженню клінічного перебігу кожного з захворювань.

Таким чином, підвищення рівня греліну крові зумовлює зниження показників оксидативного стресу - зменшення рівня тіобарбітурової кислоти крові та підвищення супероксиддисмутази, а також зменшення діаметру чревного стовбура та швидкості кровотоку у ньому в усіх групах хворих. Причому, чим вищий був рівень греліну, тим меншими були показники оксидативного стресу, а при додатковому призначенні актовегіну, вони практично дорівнювали показникам хворих з контрольної групи. 
1. Адамович І. В., Вовк К. В., Літвін О. І., Ніколенко Є. Я., Бакуменко М. Г., Дергачова А. В. Аналіз захворюваності хвороб органів травлення в студентській популяції та профілактичні заходи їх подолання // Клінічна та профілактична медицина / Вісник Українська медична стоматологічна академія. - 2018. - Том 18, Вип. 3 (63). - С. 5-8.

2. Бабак М. О. Клініко-ендоскопічні особливості перебігу гастроезофагеальної рефлюксної хвороби в осіб із надлишковою масою тіла та ожирінням / М. О. Бабак // Сучасна гастроентерологія. - 2010. - №. 1(51). - С. 16-20.

3. Батько А. Б. Артериальная гипертензия и мочекаменная болезнь: патогенетические параллели / А. Б. Батько // Всероссийский междисциплинарный медицинский журнал. - 2013. - №. 1. - С. 44-48.

4. Беловол А. Н. Полиморфизм гена ангеотензинпревращающего фермента в патогенезе гипертрофии миокарда у пациентов с артериальной гипертензией в сочетании с сахарным диабетом 2 типа / А. Н. Беловол, Л. Р. Бобронникова // Український терапевтичний журнал. - 2017. №. 2. - С. 5-11.

5. Белоусов Ю. В. Коморбидность при заболеваниях пищеварительной системы / Ю. В. Белоусов // Здоровье ребенка. - 2012. - №. 1 (36). - С. 134-136.

6. Белоусова, О. Ю. Заболевания поджелудочной железы у детей, сопровождающиеся развитием эндокринной недостаточности: тактика обследования и возможности коррекции / О. Ю. Белоусова. - Сучасна гастроентерологія [Текст] : наук.-практ. спеціалізов. журн./ НАМН України. - Київ. - 2014. - № 3. - С.51-58.

7. Бичков М. А. Стиль життя та поширеність симптомів гастроезофагеальної рефлюксної хвороби у студентів / M. А. Бичков, Г. М. Магльована // Acta medica leopoliensia. - 2015. - № 4. - C. 38-43.

8. Бичков М. А., Яхницька М. М. Поширеність гастроезофагеальної рефлюксної хвороби за даними ендоскопічних досліджень//Здобутки клінічної і експериментальної медицини. 2017.- № 2.- С. 38-43.

9. Боднар П. М., Приступюк О. М., Михальчишин Г. П., Комісаренко Ю. І., Кобиляк Н. М., Приступюк Л. О. Патогенетичне обгрунтування діагностичних і лікувальних заходів у хворих на цукровий діабет 2 типу/ П. М. Боднар, О. М. Приступюк, Г. П. Михальчишин, та ін.//Медична наука України. - 2015. - Т. 11, № 3-4. - С. 37-44. - Режим доступу: http://nbuv.gov.ua/UJRN/nvnmu_2015_11_3-4_7.

10. Волошин О. І., Доголіч О. І., Волошина Л. О. Вікові та статеві аспекти коморбідної та супутньої патології у хворих на подагру (ретроспективне дослідження) / О. І. Волошин, О. І. Доголіч, Л. О. Волошина [та ін.] // Буковинський медичний вісник. - 2012. - Т. 16. - №. 2(62). - С. 20-23

11. Воронцов С. Артериальная гипертензия ихроническая болезнь почек - факторы повышенного риска формирования когнитивных нарушений / С. Воронцов, И. Макарова, М. Шумкина // Врач. - 2016. - № 12. - С. 15-17.

12. Гапонова О. Г., Просоленко К. О. Надлишкова маса тіла та функціональні розлади травного каналу / О. Г. Гапонова, К. О. Просоленко // Сучас. гастроентерологія. - 2007. № 5 . - С. $37-41$.

13. Губіна Н.В., Купновицька І.Г., Белегай Р.І., Фітковська І.П., Клименко B.I., Мартинів I.В.Роль аліментарного ожиріння у виникненні структурно-функціональних змін нирок, серця та судин /Н.В. Губіна, І.Г.Купновицька, Р.І.Белегай та ін. //«Art of medicine» 4(4) жовтень-грудень, 2017.C. $77-81$.
14. Дебрецені К. О. Біологічні аспекти гелікобактеріозу [Текст] / К. О. Дебрецені, К. І. Чопей, М. В. Ніколайчук та ін. // Науковий вісник Ужгородського університету : Серія: Біологія / редкол.: В.І. Ніколайчук (гол. ред.), В.В. Моргун, М.Я. Співак та ін. - Ужгород: Видавництво УжНУ «Говерла», 2010. - Вип. 27. - С. 64-67. - Бібліогр.: с. 66-67

15. Дзяк Г. В. Стратификация риска пациентов с хронической сердечной недостаточностью: вопросы коморбидности / Г. В. Дзяк, А. А. Ханюков // Медична газета «Здоров’я України XXI сторіччя». - 2010. - №. 3.- С. 22-23.

16. Драпкина О. М. Адипокины и сердечно-сосудистые заболевания: патогенетические параллели и терапевтические перспективы/ О. М. Драпкина, О. Н. Коренева, Н. О. Палаткина // Артериальнеая гипертензия. - 2011.— №3. C. $5-6$.

17. Журавлева Л. В. Лечение артериальной гипертензии у пациентов высокого и очень высокого кардиоваскулярного риска с коморбидной патологией / Л. В. Журавлева, Н. А. Лопина // Український медичний часопис. - 2011. №. 6 (86). - С. $24-31$.

18. Каменир В. М. Клинические особенности гастроэзофагеальной рефлюксной болезни в сочетании с хроническим обструктивным заболеванием легких / В. М. Каменир // Сучасна гастроентерологія. - 2010. №. 1 (51). - С. 39-45.

19. Корендович I.В., Бабенко Т.О. Функціональні розлади шлунково-кишкового тракту в дітей та підлітків//Практикуючий лікар. Гастроентерологія. - том 5. - 2016. №3. - С. $12-15$.

20. Кот Л.І., Богданова О.В., Остапченко Л.І. Сучасні уявлення про біохімічні механізми патогенезу інсуліннезалежного цукрового діабету / Л.І. Кот, О.В. Богданова, Л.І. Остапченко //Вісн. НАН України. - 2008. - № 9. - С. 18-26.

21. Крапивина Н.А., Артемчук Н.В., Тачкова О.А., Костин В.И. Уровень грелина у женщин молодого возраста с ожирением / Н.А. Крапивина, Н.В. Артемчук, О.А. Тачкова, В.И. Костин // Современные наукоемкие технологии. 2005. - № 4. - С. 47-48.

22. Кривенко В. І. Функціональні розлади шлунково-кишкового тракту у практиці лікаря загальної практики - ciмейної медицини: навч. посіб. / В. І. Кривенко, Т. Ю. Гріненко, С. П. Пахомова. - Запоріжжя, 2015. - 89 с.].

23. Кукушка Е. В. Коморбидность и артериальная гипертензия / Е. В. Кукушка, Т. С. Бутова, К. И. Терешкин // Коморбідні стани в клініці внутрішніх хвороб: матеріали науково-практичної конференції студентів та молодих вчених, Харків, 25 жовтня 2012 р. - ХНМУ. - Х., 2012. С. $23-24$.

24. Марушко Ю.В. Асонов А.О. Досвід використання пантопразолу у комплексній терапії захворювань травного тракту різних вікових груп //Ліки України Medicine of Ukraine № 3 (209) /2017. - С. 19-23.

25. Осьодло Г.В. Особливості перебігу та лікування кислотозалежних захворювань в учасників АТО / Г.В. Осьодло, Г.М. Шевага // Гастроентерологія. - 2015. — №23 (372). — С. $42-43$.

26. Палій І. Г. Пантопразол - інгібітор протонної помпи з доведеною переносимістю, безпечністю та ефективністю / I. Г. Палій // Сучасна гастроентерологія. - 2013. - № 1 . C. 97-104. - Режим доступу: http://nbuv.gov.ua/UJRN/ SGastro_2013_1_16.

27. Погосова Н. В., Байчоров И. Х., Юферева Ю. М. Качество жизни больных с сердечно-сосудистыми заболевани- 
ями: современное состояние проблемы / Н. В. Погосова, И. Х. Байчоров, Ю. М. Юферева [и др.] // Кардиология. 2010. - №. 4. - С. 36-41.

28. Приворотский В.Ф., Луппова Н.Е., Герасимова Т.А. и др. Гастроэзофагеальная рефлюксная болезнь (ГЭРБ) у детей // Экспер. и клин. гастроэнтерол. - 2011. - № 1. C. $14-21$.

29. Руденко Т. М. Оптимізація діагностики ендотеліальної дисфункції при артеріальній гіпертензії в поєднанні з ожирінням та іiі корекція : дис. ... канд. мед. наук : 14.01 .02 - Внутрішні хвороби / Т. М. Руденко ; Харківська медична академія післядипломної освіти. - Харків, 2015. - 175 c.

30. Синельник В. П. Показатель качества жизни как критерий лечения ликвидаторов аварии на Чернобыльской AEC, больных гипертонической болезнью коморбидной с гастроэзофагеальной рефлюксной болезнью. /В. П. Синельник, О. А. Опарин //Новости медицины Грузии. 2017. — № .4 (265). - С. 54-59. (Scopus).

31. Степанов Ю.М., Скирда І.Ю., Петішко О.П.Хронічні запальні захворювання кишечника: особливості епідеміології в Україні//Hastroenterolohiya. - 2017.- Том 51.№ 2. - C. 97-105. doi: 10.22141/2308-2097.51.2.2017.101703.

32. Тарасенко К. В. Особливості гормональної регуляції репродуктивної системи у вагітних жінок з ожирінням /К.В. Тарасенко //Клінічна та експериментальна медицина. Biсник проблем біології і медицини - $2014-$ Вип. 4, Том 3 (115). C. 204-206.

33. Фадєєнко Г. Д., Гальчінська В. Ю., Кушнір І. Е. Порушення функціонального стану ендотелію та його роль у патогенезі гастроезофагеальної рефлюксної хвороби в поєднанні з ішемічною хворобою серця / Г. Д. Фадєєнко, В. Ю. Гальчінська, І. Е. Кушнір [та ін.] // Сучасна гастроентерологія. - 2016. - № 5 (91). - С. 9-14.

34. Фадєєнко Г. Д., Можина Т. Л. Діабетична гастропатія: сучасний стан проблем/ Г. Д. Фадєєнко, Т. Л.Можина //Сучасна гастроентерологія. - 2006. - № 2. - С. 89-97.

35. Фролова-Романюк Е. Ю. Особливості клінічної картини та лікування гастроезофагеальної рефлюксної хвороби при поєднанні ії з цукровим діабетом 2 типу / Е. Ю. Фролова-Романюк // Сучасна гастроентерологія. - 2011. № 1. - C. $111-115$.

36. Харченко, Н. В. Оптимальні підходи до лікування болю при синдромі подразненого кишечника / Н. В. Харченко, I. Я. Лопух. - Сучасна гастроентерологія [Текст] : наук.практ. спеціалізов. журн./ НАМН України. - Київ. 2014. — № 3. - :С.43-48.

37. Чернобровий В. М. Гастроезофагеальна рефлюксна хвороба: функціональна діагностика, вибір інгібіторів протонної помпи та оцінка ефективності їх кислотосупресивної дії / В. М. Чернобровий, С. Г. Мелащенко, О. О. Ксенчин // Сучасна гастроентерологія. - 2015. - № 3 (83). C. 50-58.

38. Шадрін О.Г., Муквіч О.М. Гастроентерологія дітей раннього віку. - К., 2010. - С. 18-20, 52-56.

39. Шекера О.Г., Мельник Д.В. Поширеність серед дітей хвороб органів травленнята виразкової хвороби дванадцятипалої кишки -актуальна проблема сімейної медицини// Семейная медицина №1 (69). - 2017. - С. 16-20.

40. Шишкова В. Н. Развитие основних нарушений гемостаза у пациентов с ожирением / В. Н. Шишкова, А. Ю. Ременник, Л. И. Зотова // Кардиология. - 2012.— № 2, Том 52. С. $59-64$

41. Шляхов Н. В. Судинний ендотеліальний фактор росту як маркер судинних дисфункцій у дітей з ожирінням /
Н. В. Шляхов, О. А. Будрейко, С. О. Чумак // Проблеми ендокринної патології. - 2012.—№ 1.- С. 26-32.

42. Щеглюк О.І., Желеховський О.А. Особливості та структура захворюваності органів травлення серед військовослужбовців збройних сил україни в сучасних умовах ведення бойових дій// Актуальні питання сучасної науки/м. Івано-Франківськ, 7-8 липня 2017. - С. 72-75.

43. Щорічна доповідь про стан здоров'я населення, санітарно-епідемічну ситуацію та результати діяльності системи охорони здоров'я України, 2015 р. / За ред. В.В. Шафранського - Київ, 2016. - 425 с.

44. Barazzoni R., Zhu X., Deboer M., Datta R. et al. Combined effects of ghrelin and higher food intake enhance skeletal muscle mitochondrial oxidative capacity and AKT phosphorylation in rats with chronic kidney disease // Clinica Medica-Department of Clinical, Morphological and Technological Sciences, University of Trieste, Trieste, Italy, Kidney Int. 2010 Jan;77(1): P.269-285.

45. Bol'shova OV, Malinovs'ka TM. Serum Ghrelin level in adolescents with hypothalamic dysfunction associated with obesity. In: International Conference on Childhood Obesity. 2017 July 5-8; Lisbon, Portugal. Lisbon; 2017. - 89 p.

46. Bradbury KE, Appleby PN, Key TJ. Fruit, vegetables, and fiberintake in relation to cancer risk: findings from the European Prospective Investigation into Cancer and Nutrition (EPIC). Am JClin Nutr. 2014 Jul;100:394S-8S. doi: 10.3945/ ajcn.113.071357.

47. Broglio F., Gottero C., Arvat E., Ghigo E. Hormone Research, Endocrine and Non-Endocrine Actions of Ghrelin // Hormone Research 2003; 59 (3): P.109-117.

48. Büscher A.K., Büscher R., Hauffa B.P., Hoyer P.F. Alterations in appetite-regulating hormones influence protein-energy wasting in pediatric patients with chronic kidney disease// Pediatr Nephrol. 2010 Nov;25(11): P. 295-301.

49. Choi K, Roh S-G, Hong Y-H, et al. The role of ghrelin and growth hormone secretagogues receptor on rat adipogenesis. Endocrinology. 2003;144(3):754—759. [PubMed]

50. Date Y1,Kojima M,Hosoda H,Sawaguchi A,Mondal MS,Suganuma T,Matsukura S,Kangawa K,Nakazato M. Ghrelin, a Novel Growth Hormone-Releasing Acylated Peptide, Is Synthesized in a Distinct Endocrine Cell Type in the Gastrointestinal Tracts of Rats and Humans. Endocrinology, Volume 141, Issue 11, 1 November 2000, Pages 4255-4261,https://doi.org/10.1210/endo.141.11.7757.

51. Deboer M.D., Zhu X., Levasseur P.R., Inui A. et al. Ghrelin treatment of chronic kidney disease: improvements in lean body mass and cytokine profile // Endocrinology 2008; 149 (2): P.827-835.

52. Dimaraki EV, Jaffe CA. Role of endogenous ghrelin in growth hormone secretion, appetite regulation and metabolism. Rev Endocr Metab Disord. 2006 Dec;7(4):237-49. doi: 10.1007/ s11154-006-9022-0.

53. Dyspeptic symptoms in the general population: A factor and cluster analysis of symptom groupings / H. Piessevaux, B. De Winter, E. Louis [et al.] // Neurogastroenterol Motil. - 2009. - Vol. 21. - P. 378-388.

54. Elsayed N.M., Hamed S.T., El-Khatib M.M., El-Shehaby A.M. The relation between dual energy x-ray absorptiometry measurement of body fat composition and plasma ghrelin in patients with end-stage renal disease// Saudi Med J. 2009 Jan;30(1): P.109-15.

55. Fischbach L.A., Nordenstedt H., Kramer J.R. et al. The association between Barrett's esophagus and Helicobacter pylori infection: a meta-analysis // Helicobacter. - 2012. Vol. 17. - P. $163-175$. 
56. Fox J.G., Kuipers E.J. Long-term proton pump inhibitor administration, $\mathrm{Hp}$ and gastric cancer: lessons from the gerbil // Gut. - 2011. - Vol. 60. - P. 567-568.

57. Freedman ND, Subar AF, Hollenbeck AR, Leitzmann MF, Schatzkin A, Abnet CC. Fruit and vegetable intake and gastric cancer in a large United States prospective cohort study. Cancer Causes Control. 2008 Jun;19(5):459-67. doi: 10.1007/ s10552-007-9107-4.

58. G. V. Grigoruk, V. G. Mischuk Ефективність різних комбінацій антигіпертензивних препаратів у хворих із високим рівнем артеріального тиску на тлі ожиріння і синдрому подразненої кишки із закрепами.// Вісник наукових досліджень.- № 1 (2019)._- C. 23-27 DOI:https://doi. org/10.11603/2415-8798.2019.1

59. Gualillo O, Lago F, Gómez-Reino J, Casanueva FF, Dieguez C. Ghrelin, a widespread hormone: insights into molecular and cellular regulation of its expression and mechanism of action. FEBS Letters. 2003;552(2-3):105-109. [PubMed]

60. Guebre-Egziabher F, Bernhard J, Geelen G. Leptin, Adiponectin, and Ghrelin Dysregulation in Chronic Kidney Disease // J Renal Nutrition 2005; 15 (1): P.116-120.

61. Jarkovska Z., Rosicka M., Krsek M., Sulkova S. et al. Plasma ghrelin levels in patiens with End-Stage Renal Disease // Phisiological Research 2005 54: P.403-408.

62. Joossens JV, Hill MJ, Elliott P, Stamler R, Lesaffre E, Dyer A, et al. Dietary salt, nitrate and stomach cancer mortality in 24 countries. Int J Epidemiol. 1996; 25:494-504.].

63. Kato I, Vivas J, Plummer M, Lopez G, Peraza S, Castro D, et al.Environmental factors in Helicobacter pylori-related gastricprecancerous lesions in Venezuela. Cancer Epidemiol Biomarkers Prev. 2004; 13:468-76.

64. Kirchner H, Heppner KM, Tschöp MH. The role of ghrelin in the control of energy balance. Handb Exp Pharmacol. 2012;(209):161-84. doi: 10.1007/978-3-642-24716-3_7.

65. Kojima M, Hosoda H, Date Y, Nakazato M, Matsuo H, Kangawa K. Ghrelin is a growth-hormone-releasing acylated peptide from stomach. Nature. 1999 Dec 9;402(6762):656-60. doi: $10.1038 / 45230$.

66. Kojima M, Hosoda H, Matsuo H, Kangawa K. Ghrelin: discovery of the natural endogenous ligand for the growth hormone secretagogue receptor. Trends in Endocrinology and Metabolism. 2001;12(3):118-122. [PubMed]

67. Korbonits M, Goldstone AP, Gueorguiev M, Grossman AB.Ghrelin - a hormone with multiple functions Front Neuroendocrinol. 2004 Apr;25(1):27-68. Review. PMID:15183037.

68. MalikV. Global obesity: trends, risk factors and policy implications / V.Malik, S., Willett// Nat. Rev. Endocrinol. 2013. - Vol.9. - P. 13-27.

69. Matsuda K., Nishi Y., Okamatsu Y., Kojima M. et al. Ghrelin and leptin: a link between obesity and allergy // Journal of allergy and clinical Immunology (St Louis MO) 2006; 117 (3): P.705-706.

70. Meier U1, Gressner AM.Endocrine regulation of energy metabolism: review of pathobiochemical and clinical chemical aspects of leptin, ghrelin, adiponectin, and resistin. Clin.Chem. 2004 Sep;50(9):1511-25. Epub 2004 Jul 20.PMID: 15265818 DOI: $10.1373 /$ clinchem.2004.032482.

71. Murakami N., Hayashida T., Kuroiwa T., Nakahara K. Role for central ghrelin in food intake and secretion profile of stomach ghrelin in rats // J. Endocrinol._ 2002.— № 174 (2).— P. 283288.

72. Murray C.D., Martin N.M., Patterson M., Taylor S.A. Ghrelin enhances gastric emptying in diabetic gastroparesis: a double blind, placebo controlled, crossover study // Gut.- 2005.№ 54(12). - P. 1693-1698.
73. Nagaya N, Moriya J, Yasumura Y, et al. Effects of ghrelin administration on left ventricular function, exercise capacity, and muscle wasting in patients with chronic heart failure. Circulation. 2004; 110(24):3674-3679. [PubMed]

74. Naufel M.F., Bordon M., de Aquino T.M., Ribeiro E.B., de Abreu Carvalhaes Plasma levels of acylated and total ghrelin in pediatric patients with chronic kidney disease. JT Pediatr Nephrol. 2010 Dec;25(12): P.2477-82.

75. Osawa H. Ghrelin and Helicobacter pylori infection // World J Gastroenterol 2008; 14 (41): P. 6327-6333.

76. Popovic V. Ghrelin // Current Opinion in Endocrinology @ diabetes 2006; 13: P.70-75.

77. Purnell JQ, Weigle DS, Breen P, Cummings DE. Ghrelin levels correlate with insulin levels, insulin resistance, and high-density lipoprotein cholesterol, but not with gender, menopausal status, or cortisol levels in humans. J Clin Endocrinol Metab. 2003 Dec;88(12):5747-52. doi: 10.1210/ jc.2003-030513.

78. Rome III The Functional Gastrointestinal Disorders / D. Drossman, E. Corazziari, M. Delvaux [et al.] // Yale University Section of Digestive Disease: Degnon Associates, 2006. - Ed. 3.- $1052 \mathrm{p}$.

79. Sato T, Nakamura Y, Shiimura Y, Ohgusu H, Kangawa K, Kojima M. Structure, regulation and function of ghrelin. J Biochem. 2012 Feb;151(2):119-28. doi: 10.1093/jb/mvr134.

80. Simonian H.P., Kresge K.M., Boden G.H., Parkman H.P. Differential effects of sham feeding and meal ingestion on ghrelin and pancreatic polypeptide levels: evidence for vagal efferents stimulation mediating ghrelin release // Neorogastroenterol Motil 2005; 17: P. 348-354.

81. Soltani Z.I., WashcoV., Morse S., Reisin E. The impacts of obesity on the cardiovascularand renal systems: cascade of events and therapeuticapproaches / Z.I. Soltani, V. Washco, S.Morse, E. Reisin // Curr Hypertens Rep. - 2015,Feb. - Vol. 17 (2). - P.7-9.

82. StepanovY.M.Digestivediseasesandgastroenterologicalservices to the population of Ukraine: achievements, problems and solutions. Zdorov'ja Ukrai'ny. Gastroenterologiya. 2014 September;3:10-1. (in Ukrainian).

83. Taylor M.S., Hwang Y., Hsiao P.Y. Ghrelin O-acyltransferase assays and inhibition// Methods Enzymol. 2012;514: P.205-28.

84. Thompson NM, Gill DA, Davies R, et al. Ghrelin and desoctanoyl ghrelin promote adipogenesis directly in vivo by a mechanism independent of the type 1a growth hormone secretagogue receptor. Endocrinology. 2004;145:234-242. [PubMed].

85. Tsugane S, Kabuto M, Imai H, Gey F, Tei Y, Hanaoka T, et al. Helicobacter pylori, dietary factors, and atrophic gastritis in five Japanese populations with different cancer mortality. Cancer Causes Control. 1993 Jul;4:297-305.

86. Tzotzas T. Obesity, weight loss and conditional cardiovascular risk factors / T. Tzotzas, P. Evangelou, D. N. Kiortsis // Obesity Reviews. - 2011. - Vol. 12, №5. - P. 282-289.

87. Vandenplas Y., Rudolph C.D., Di Lorenzo C. et al. Pediatric gastroesophageal reflux clinical practice guidelines: joint recommendations of the North American Society for Pediatric Gastroenterology, Hepatology and Nutrition (NASPGHAN) and the European Society for Pediatric Gastroenterology, Hepatology and Nutrition (ESPGHAN) // J. Pediatr. Gastroenterol. Nutr. - 2009. - Vol. 49. - P. 498-454.

88. Varela L, Vázquez MJ, Cordido F, et al. Ghrelin and lipid metabolism: key partners in energy balance. J Mol Endocrinol. 2011;46(2):R43-63. doi: 10.1677/JME-10-0068.

89. Vera Popovic \& Leonidas H. Duntas (2005)Brain somatic cross-talk: Ghrelin, leptin and ultimate 
challengers of obesity, Nutritional Neuroscience,8:1,1-5, DOI:10.1080/10284150400027107.

90. Wang XQ, Terry PD, Yan H. Review of salt consumption and stomach cancer risk: epidemiological and biological evidence. World J Gastroenterol. 2009 May;15(18):2204-13. doi:10.3748/ wjg.15.2204

91. Wiedmer P., Nogueiras R., Broglio F., D’Alessio D.,Tschöp M.H. Ghrelin, obesity and diabetes // Nat.Clin. Pract. Endocrinol. Metab. - 2007. — Vol. 3. — №10. - P. 705-712.

92. Wiley KE, Davenport AP. Comparison of vasodilators in human internal mammary artery: ghrelin is a potent physiological antagonist of endothelin-1. British Journal of Pharmacology. 2002; 136(8):1146-1152. [PMC free article] [PubMed].

93. Wirth H-P, Yang M. Different Pathophysiology of Gastritis in East and West? A Western Perspective. Inflamm Intest Dis. 2016; 1(3):113-22. doi:10.1159/000446300.
94. Wittert G., Chapman I. Physiology of gut hormones an overview // Current Opinion in Endocrinology and Diabetes (Hagerstown, Md) 2006; 13 (1): P.36-4

95. Yacavone RF, Locke 3rd GR, Provenzale DT, Eisen GM. Quality of life measurement in gastroenterology: what is available? Am J Gastroenterol. $2001 \mathrm{Feb}$; 96(2):285-97.

96. Yang Y.J., Sheu B.S., Yang H.B., Lu C.C., Chuang C.C. Eradication of Helicobacter pylori increases childhood growth and serum acylated ghrelin levels // World J Gastroenterol. 2012 Jun 7;18(21):P.2674-81.

97. Zizzari P., Halem H., Taylor J. et al. Endogenous ghrelin regulates episodic GH secretion by amplifying GH pulse amplitude evidence from antagonism of the GHS-R1a receptor // Endocrinology 2005; 146: P.3836-3842.

\section{Роль и место грелина в патологии заболеваний органов желудочно-кишечного тракта}

\section{Кудрявцев А.А.}

Харьковская медицинская академия последипломного образования

Кафедра терапии, ревматологии и клинической фармакологии

На сегодняшний день заболевания органов пищеварения остаются одной из наиболее актуальных проблем современной медицины. Значительное внимание ученые уделяют биохимическим и молекулярным механизмам, лежащие в основе развития этих патологий. За последние годы открыты новые гормоны и нейромедиаторы, которые регулируют энергетический обмен и пищевое поведение, в том числе грелин (ghrelin) - гастроинтестинальный гормон, обладающий различными биологическими особенностями и эффектами: стимулирует высвобождение гормона роста, стимулирует аппетит, обладает анаболическим действием, влияет на углеводный обмен. Основной сайт синтеза грелина - желудок, на 2 месте - двенадцатиперстная кишка, менее выражены концентрации определяются во всем желудочнокишечном тракте, но уменьшаются в дистальном направлении.

Учеными доказано, что грелин влияет на аппетит не только прямой передачей сигналов к ромбовидному мозгу, но и через блуждающий нерв, поскольку его эфферентные пути стимулируют высвобождение грелина.

На современном этапе известны биологические эффекты грелина, а именно регуляция аппетита, анаболические эффекты, влияние на секрецию гормонов, сердечно-сосудистую систему, желудочно-кишечный тракт, костную ткань а также способность к ингибированию иммуноглобулина Е.

Изучение концентрации грелина в плазме крови у пациентов с ГЭРБ и сахарным диабетом (СД) 2-го типа у лиц молодого возраста стало частью нашего исследования. Показано, что концентрация грелина снижается при различных метаболических процессах, в том числе при сахарном диабете 2-го типа.

Для получения результатов мы исследовали четыре группы пациентов с ГЭРБ с сопутствующим сахарным диабетом 2-го типа легкой и средней тяжести и изолированной ГЭРБ.

Нами установлено, что на фоне проведения 4-х-недельного курса лечения у пациентов всех четырех групп увеличился уровень грелина и снизились показатели окислительного стресса.

Полученные данные позволили уточнить взаимосвязь грелина с оксидативным стрессом при наличии коморбидного течения ГЭРБ с СД 2-го типа у лиц молодого возраста. Таким образом, результаты, полученные нами в ходе исследования, свидетельствуют, что грелин играет важную роль в формировании коморбидного течения ГЭРБ с СД 2-го типа у лиц молодого возраста и констатируют, что изменения уровня грелина является одним из факторов, значительно отягощим клиническое течение ГЭРБ с СД 2-го типа.

Также следует отметить, что одновременно с нормализацией уровня грелина в группах пациентов, страдающих СД 2-го типа, отмечалась четкая тенденция к стабилизации гликемического профиля, что свидетельствует о тесной связи между этим гормоном и клиническим течением сахарного диабета 2-го типа .

Полученные данные позволяют утверждать, что, во-первых, грелин играет важную роль в патогенезе и клиническом течении этой коморбидной патологии; во-вторых, изменения уровня грелина и оксида- 
тивный стресс являются одним из пусковых механизмов формирования ГЭРБ в сочетании с сахарным диабетом 2-го типа у лиц молодого возраста, в-третьих, грелин способствует обременению клинического течения каждого из заболеваний.

Таким образом, повышение уровня грелина крови приводит к снижению показателей оксидативного стресса - уменьшение уровня тиобарбитуровой кислоты крови и повышение супероксиддисмутазы, а также уменьшение диаметра чревного ствола и скорости кровотока в нем во всех группах больных. Причем, чем выше был уровень грелина, тем меньше были показатели оксидативного стресса, а при дополнительном назначении актовегина, они практически равны показателям больных из контрольной группы.

Ключевые слова: грелин, оксидативный стресс, гастроэзофагеальная рефлюксная болезнь, болезни органов пищеварения, актовегин.

\section{The role and place of ghrelin in the pathology of diseases of the gastrointestinal tract}

\section{Kudryavtsev A.A.}

Kharkiv Medical Academy of Postgraduate Education

Department of Therapy, Rheumatology and Clinical Pharmacology

To date, diseases of the digestive system remain one of the most pressing problems of modern medicine. Much attention is paid to the biochemical and molecular mechanisms underlying the development of these pathologies. In recent years, new hormones and neurotransmitters have been discovered that regulate energy metabolism and nutritional behavior, including ghrelin - a gastrointestinal hormone that has various biological features and effects: stimulates the release of growth hormone, stimulates appetite, has an effect on appetite, metabolism. The main site of ghrelin synthesis is the stomach, the duodenum in 2 place, less pronounced concentrations are determined in the entire gastrointestinal tract, but decrease in the distal direction.

Scientists have shown that ghrelin affects appetite not only by direct signaling to the rhombus brain, but also through the vagus nerve, since its efferent pathways stimulate the release of ghrelin.

At the present stage, the biological effects of ghrelin are known, namely the regulation of appetite, anabolic effects, the influence on hormone secretion, the cardiovascular system, the gastrointestinal tract, bone tissue, and has the ability to inhibit immunoglobulin E.

The study of ghrelin concentration in blood plasma in patients with GERD and type 2 diabetes mellitus in young people was part of our study. It is shown that the concentration of ghrelin decreases with various metabolic processes, including with type 2 diabetes.

To obtain results, we examined four groups of patients with GERD with concomitant type 2 diabetes mellitus of mild to moderate severity and isolated GERD.

We found that the background of conducting a 4-week course of treatment in patients of all four groups increased the level of ghrelin and decreased indicators of oxidative stress.

The obtained data made it possible to clarify the relationship of ghrelin with oxidative stress in the presence of comorbid course of GERD with type 2 diabetes in young people. Thus, the results obtained during the study indicate that ghrelin plays an important role in the formation of a comorbid course of GERD with type 2 diabetes in young people and conclude that changes in ghrelin levels are one of the factors that significantly burden the clinical course of GERD with type 2 diabetes.

It should also be noted that, at the same time as the normalization of ghrelin levels in groups of patients with type 2 diabetes, there was a clear tendency to stabilize the glycemic profile, indicating a close relationship between this hormone and the clinical course of type 2 diabetes.

The data obtained suggest that, first, ghrelin plays an important role in the pathogenesis and clinical course of this comorbid pathology; second, changes in ghrelin levels and oxidative stress are one of the triggers of GERD in combination with type 2 diabetes in young people, and thirdly, ghrelin contributes to the clinical course of each disease.

Thus, an increase in blood ghrelin leads to a decrease in oxidative stress - a decrease in the level of thiobarbituric acid in the blood and an increase in superoxide dismutase, as well as a decrease in the diameter of the intestinal trunk and the blood flow velocity in it in all patient groups. Moreover, the higher the ghrelin level, the less were the indicators of oxidative stress, and with the additional appointment of actovegin, they are almost equal to the patients in the control group.

Key Words: ghrelin, oxidative stress, gastroesophageal reflux disease, digestive diseases, actovegin. 